\title{
Density and distribution of nests of Mycetophylax simplex (Emery) (Hymenoptera, Formicidae) in areas with mobile dunes on the northern coast of Rio Grande do Sul, Brazil
}

\author{
Emília Z. de Albuquerque ${ }^{1,2}$, Eduardo Diehl-Fleig ${ }^{3} \&$ Elena Dieh1 ${ }^{1,4}$
}

\begin{abstract}
'Programa de Pós-Graduação em Biologia, Universidade do Vale do Rio dos Sinos. Caixa Postal 275, 93001-970 São Leopoldo-RS, Brasil. ${ }^{2}$ emilia albuq@hotmail.com

${ }^{3}$ Programa de Pós-Graduação em Entomologia, Escola Superior de Agricultura "Luiz de Queiroz"/Universidade de São Paulo. Caixa

Postal 9, 13418-900 Piracicaba-SP, Brasil. edudiehl@carpa.ciagri.usp.br

${ }^{4}$ Pesquisador CNPq. ediehl@bios.unisinos.br
\end{abstract}

\begin{abstract}
Density and distribution of nests of Mycetophylax simplex (Emery) (Hymenoptera, Formicidae) in areas with mobile dunes on the northern coast of Rio Grande do Sul, Brazil. Studies on lower attines are scarce, especially on nesting and foraging ecology and behavior. This study aimed to contribute to the knowledge of an Attini in dunes ecosystems through the description of density and spatial distribution of Mycetophylax simplex (Emery, 1887) nests in a strip of mobile dunes in the Praia Grande beach, Torres, northern coast of Rio Grande do Sul, Brazil. The density and spatial distribution of nests were estimated in four plots of 2,500 $\mathrm{m}^{2}$ each, in which were found 20, 209, 284 and 324 nests, with average densities of 0.01 nests $/ \mathrm{m}^{2}, 0.09,0.11$ and 0.13 nests $/ \mathrm{m}^{2}$, respectively. The nests were found near to the vegetation and showed clumped distribution. The density and distribution pattern of the nests seem to be related to the availability of nesting places and foraging resources.
\end{abstract}

KEYwords. Attini; fungus growing ants; Myrmicinae; sand dunes.

\begin{abstract}
Resumo. Densidade e distribuição de ninhos de Mycetophylax simplex (Emery) (Hymenoptera, Formicidae) em área de dunas móveis no litoral norte do Rio Grande do Sul, Brasil. Estudos sobre as atinis inferiores são escassos, principalmente em relação ao comportamento e ecologia da nidificação e do forrageamento. Este estudo objetivou contribuir ao conhecimento da tribo Attini em ecossistemas de dunas, através da descrição da densidade e da distribuição espacial dos ninhos de Mycetophylax simplex (Emery, 1887) em uma faixa de dunas móveis na praia Grande, município de Torres, litoral norte do Rio Grande do Sul. A densidade e distribuição espacial dos ninhos foram estimadas em quatro parcelas de $2.500 \mathrm{~m}^{2}$ cada, nas quais foram encontrados 20, 209, 284 e 324 ninhos, com densidades médias, de 0,01 ninhos $/ \mathrm{m}^{2}, 0,09$, 0,11 e 0,13 ninhos $/ \mathrm{m}^{2}$, respectivamente. Os ninhos encontravam-se próximos à vegetação e com distribuição agregada. É sugerido que a densidade e o padrão de distribuição dos ninhos estariam relacionados à disponibilidade de locais de nidificação e à presença de recursos para forrageamento.
\end{abstract}

Palavras-Chave. Attini; dunas; formigas cultivadoras de fungos; Myrmicinae.

The distribution of Attini is limited to the New World, where most species are found in the Neotropical region and only 5\% in the Nearctic region (Mayhé-Nunes 1995a). The most derived (higher) Attini belong to Atta (Fabricius, 1804) and Acromyrmex (Mayr, 1865), called leaf-cutting ants because they maintain fungus cultures exclusively on many different species of plants. Due to their status of pest in farming and reforestation, these are the most studied genera (see Mariconi 1970; Della Lucia 1993; Diehl-Fleig 1995). The other genera (lower Attini) use organic matter, faeces and decomposing animals remains to cultivate their "garden" or "sponge" of the symbiontic fungus on which they feed, and therefore don't harm crops and are less studied. Mayhé-Nunes (1995b) studied Mycetarotes (Emery, 1913), and Lopes (2001) Cyphomyrmex morschi Emery, 1887. However, more studies on their biology are still needed, especially on the ecology of nesting and foraging behavior.

According to Mayhé-Nunes (1995a) the genus Mycetophylax (Emery, 1913) occurs preferentially on sandy soils, poor in nutrients and susceptible to great disturbances, and there are no records of this genus in forest environments. The genus is distributed all over South America and has, according to Weber (1982), the state of São Paulo, Brazil, as its southern limit. However, Kempf (1972) already made records of M. simplex in Rio Grande do Sul state (São Lourenço). Gianuca (1997), studying the coast of the same State, between Cassino beach and the Estação Ecológica do Taim, also recorded this species.

The spatial distribution of organisms has been considered a central question in ecology, explaining the growing interest of ecologists in the spatial structure of organisms, especially of plants and social insects (Assunção 2000). Some biotic and abiotic factors are considered important to explain nest distribution of ant species, as, for example: soil texture and composition, humidity and other physical parameters as, distribution and abundance of food resources and competition (Warburg \& Steinberger 1997). One of the most frequently described pattern in spatial distribution of ant nests is the homogeneous distribution, when colonies are more evenly 
distributed than expected due to the resources distribution, indicating the occurrence of intra- or interspecifical competition for food and/or space (Cole et al. 2001).

In order to contribute to the knowledge of an Attini in dune ecosystems, the density and spatial distribution of $M$. simplex nests in a remnant strip of mobile dunes on Praia Grande beach, Torres city, northern coast of Rio Grande do Sul, were assessed.

\section{MATERIAL AND METHODS}

Study area. The study was realized from July to December 2002 in a strip of mobile dunes on Praia Grande beach (29 $20^{\prime}$ S; $49^{\circ} 43^{\prime} \mathrm{W}$ ), in Torres, northern coast of Rio Grande do Sul, Brazil. It climate is characterized by mild temperatures, dry with an yearly average of $24^{\circ} \mathrm{C}$, hot summers with temperatures up to $35^{\circ} \mathrm{C}$, and mild winters, generally with the highest wintertemperatures of the state. The rainfall is generally over 1,200 $\mathrm{mm}$ per year (Cordazzo \& Seeliger 1995), with a slight accumulation in November and December. The dune vegetation is very scarce, mostly interrupted by marshes (Rambo 1954) and limited to few species, mainly of crawling and pioneer plants. In this ecosystem predominate grasses, Compositae, Cyperaceae and Leguminosae (Waechter 1985), groups with adaptations that allow their survival in environments susceptible to disturbances, such as: constant sand movement, fluctuation in soil surface temperature, little water retention on the highly porous poor in nutrients substrate, and subject to marine sprinkling (Rambo 1994; Cordazzo \& Seeliger 1995).

Density and spatial distribution of M. simplex nests. The estimation of $M$. simplex nests density was made in four randomly outlined plots of $50 \mathrm{~m} \times 50 \mathrm{~m}$ (plots A, B, C and D), far from each other by nearly $100 \mathrm{~m}$, totalizing $10,000 \mathrm{~m}^{2}$ of evaluated area. In each plot nests of $M$. simplex were identified, counted and recorded, and the average nest densities in the plots and in the total area and respective deviations calculated (Zar 1999).

To find the spatial distribution model of the nests, the four plots were divided into 25 quadrats of $10 \mathrm{~m}$ x $10 \mathrm{~m}$ each. In each quadrat of $100 \mathrm{~m}^{2}$ the nests were identified and counted. To calculate the standardized index of Morisita, that determines the kind of distribution, the statistical program NEGBINOM (Krebs 1989) was used.

To calculate the nearest neighbor distances of the nests the plots $\mathrm{C}$ and $\mathrm{D}$ were used, divided into 25 quadrats of $10 \mathrm{~m}$ $\mathrm{x} 10 \mathrm{~m}$ each, and these subdivided again in quadrats of $1 \mathrm{mx} 1$ $\mathrm{m}$. In these plots of $1 \mathrm{~m}^{2}$ the position of each nest of $M$. simplex in relation to the grading lines was recorded. For the analysis of the nearest neighbor distances the statistical program MULTIV version 2.1.1 (Pillar 2000) was used. The data from the multivariate analysis indicate the average nearest neighbor distance.

Worker ants of $M$. simplex found in the study site were collected and stored in vials with $70 \%$ alcohol for taxonomic identification in laboratory. The voucher material is stored in the Coleção de Formicidae do Laboratório de Genética de
Table I. Number of nests of Mycetophylax simplex found in the quadrats $\left(100 \mathrm{~m}^{2}\right)$ in four plots of $2,500 \mathrm{~m}^{2}$ in a strip of mobile dunes in Praia Grande beach, Torres - RS, Brazil.

\begin{tabular}{ccccc}
\hline & \multicolumn{4}{c}{ Plots* } \\
& A & B & C & D \\
\hline Total number of nests/plot & 20 & 209 & 284 & 324 \\
Average number of nests/quadrat & 0.80 & 8.71 & 11.36 & 12.96 \\
Average density of nests/m ${ }^{2}$ & 0.01 & 0.09 & 0.11 & 0.13 \\
\hline
\end{tabular}

* 25 quadrats/plot.

Insetos Sociais, Universidade do Vale do Rio dos Sinos (UNISINOS), São Leopoldo, RS.

\section{RESULTS ANDDISCUSSION}

On the strip of mobile dunes in Praia Grande beach, 837 nests of M. simplex were found, from which 20 were found in the plot A, 209 in the plot B, 284 in the plot C and 324 in the plot D (Table I). The number of nests per plot did not differ significantly between the plots $\mathrm{C}$ and $\mathrm{D}\left(\mathrm{X}_{\text {yates }}^{2}=2.505\right.$; g.l. $=1$; $\mathrm{P}>0.05)$, but there was a significant difference when all four plots were considered $\left(\mathrm{X}^{2}=260.796 ;\right.$ g.l. $\left.=3 ; \mathrm{P}<0.001\right)$.

The average nest density was 0.08 nests $/ \mathrm{m}^{2}$ in the total area, with a variation among the plots from 0.01 to 0.13 nests/ $\mathrm{m}^{2}$ (Table I). In a study on nest density of some species of lower Attini (Mycocepurus smithi Forel, 1893; Myrmicocrypta buenzlii Borgmeier, 1934; Sericomyrmex urichi Forel, 1912 and Trachymyrmex urichi Forel, 1893), Weber (1982) found 51 nests in an area of $81 \mathrm{~m}^{2}$, or one nest in $1.6 \mathrm{~m}^{2}$. In an adjacent place he found 36 nests in an area of $20.25 \mathrm{~m}^{2}$, that is, one nest in 0.56 $\mathrm{m}^{2}$. Lopes (2001) analyzed the density of nests of Cyphomyrmex morschi in the dunes of Joaquina beach in Florianópolis, Santa Catarina, Brazil in three areas of $100 \mathrm{~m}^{2}$ each, where found 23 nests/area (what means, at maximum one nest at each $25 \mathrm{~m}^{2}$ and, at least, one at each $4.34 \mathrm{~m}^{2}$ ). For $M$. simplex, considering the four plots, an average of one nest at each $11.94 \mathrm{~m}^{2}$ was found. But if the plot A is not considered, because of its different characteristics (as vegetation absence, flooding in the winter), the average is one nest in each $9.18 \mathrm{~m}^{2}$. These results are within the limits found by the authors cited above, but the differences in nest densities may reflect variations in local conditions, because the plots differ in the density of vegetation as well as water retention after rain. According to Ricklefs (1993), densities provide a better basis to compare ecological relations than the total size of populations.

The spatial pattern of nests of M. simplex found in the four plots of 2,500 $\mathrm{m}^{2}$ with the standardized Morisita index (Ip $=0.500$ with $95 \%$ confidence) indicates a clumped nest distribution. The spatial arrangement of nests is probably related to the physical characteristics of the environment, distribution and availability of foraging resources and to the availability of nesting places. That is clearly observed in the plot A, characterized by the nearly complete absence of 
Table II. Minimum, maximum and average (+/- standard deviation) distances and variance among the nests of Mycetophylax simplex in two plots of $2.500 \mathrm{~m}^{2}$ in a strip of mobile dunes in Praia Grande beach, Torres - RS, Brazil.

\begin{tabular}{ccccccccc}
\hline \multicolumn{7}{c}{ Plot C } & \multicolumn{7}{c}{ Plot D } \\
\hline Quad. & $\mathrm{N}$ & Min. - Max. & $\mathrm{X}(+/ \mathrm{s})$ & $\mathrm{s}^{2}$ & $\mathrm{~N}$ & Min. - Max. & $\mathrm{X}(+/$-s $)$ & $\mathrm{s}^{2}$ \\
\hline 1 & 17 & $0.40-2.45$ & $1.18(0.59)$ & 0.35 & 15 & $1.02-2.14$ & $1.49(0.33)$ & 0.11 \\
2 & 17 & $0.47-3.66$ & $1.52(0.86)$ & 0.74 & 21 & $0.74-2.74$ & $1.72(0.57)$ & 0.32 \\
3 & 24 & $0.10-2.57$ & $1.31(0.72)$ & 0.51 & 15 & $0.80-3.16$ & $1.74(0.56)$ & 0.31 \\
4 & 9 & $1.19-4.06$ & $2.13(0.99)$ & 0.98 & 12 & $0.39-3.16$ & $1.66(1.01)$ & 1.02 \\
5 & 5 & $0.85-5.89$ & $2.87(2.76)$ & 7.63 & 14 & $0.13-3.64$ & $1.65(0.89)$ & 0.79 \\
6 & 5 & $0.51-5.47$ & $2.10(2.02)$ & 4.10 & 15 & $0.75-2.64$ & $1.55(0.54)$ & 0.29 \\
7 & 10 & $1.42-5.87$ & $2.60(1.37)$ & 1.88 & 8 & $1.87-3.88$ & $2.91(0.86)$ & 0.73 \\
8 & 22 & $0.45-4.56$ & $1.49(0.98)$ & 0.96 & 20 & $0.27-2.20$ & $1.30(0.52)$ & 0.27 \\
9 & 18 & $0.58-3.67$ & $1.78(0.71)$ & 0.50 & 12 & $0.82-2.71$ & $1.63(0.65)$ & 0.42 \\
10 & 14 & $0.52-3.90$ & $1.79(1.08)$ & 1.18 & 28 & $0.35-2.58$ & $1.18(0.54)$ & 0.30 \\
11 & 15 & $0.43-2.29$ & $0.31(0.59)$ & 0.35 & 30 & $0.74-2.60$ & $1.29(0.41)$ & 0.17 \\
12 & 8 & $0.81-4.26$ & $1.76(1.41)$ & 1.99 & 13 & $0.33-2.44$ & $1.07(0.58)$ & 0.34 \\
13 & 4 & $0.19-6.54$ & $2.45(3.01)$ & 9.07 & 2 & 9.37 & $9.37(-)$ & - \\
14 & 31 & $0.10-2.13$ & $1.05(0.79)$ & 0.35 & 8 & $1.10-4.05$ & $2.03(1.17)$ & 1.37 \\
15 & 6 & $0.60-1.06$ & $0.90(0.23)$ & 0.05 & 4 & $2.65-3.95$ & $3.25(0.69)$ & 0.48 \\
16 & 1 & - & - & - & 12 & $0.20-4.88$ & $1.88(1.27)$ & 1.60 \\
17 & 1 & - & - & - & 18 & $0.69-2.83$ & $1.65(0.56)$ & 0.31 \\
18 & 2 & 2.94 & $2.94(-)$ & - & 5 & $1.97-5.97$ & $3.12(1.65)$ & 2.73 \\
19 & 4 & $0.89-3.72$ & $2.31(1.64)$ & 2.68 & 5 & $1.08-7.09$ & $2.62(2.60)$ & 6.76 \\
20 & 13 & $0.37-3.36$ & $1.39(0.81)$ & 0.65 & 9 & $0.52-4.46$ & $2.00(1.73)$ & 3.00 \\
21 & 4 & $1.04-2.41$ & $1.51(0.65)$ & 0.42 & 10 & $0.77-3.57$ & $2.18(0.84)$ & 0.71 \\
22 & 15 & $0.13-2.62$ & $1.33(0.68)$ & 0.46 & 9 & $0.79-4.16$ & $2.32(1.34)$ & 1.79 \\
23 & 7 & $0.94-5.90$ & $2.58(1.82)$ & 3.32 & 15 & $0.17-2.33$ & $1.51(0.86)$ & 0.74 \\
24 & 25 & $0.54-2.61$ & $1.08(0.38)$ & 0.15 & 14 & $1.13-4.15$ & $1.89(0.80)$ & 0.65 \\
25 & 7 & $1.27-3.61$ & $1.98(0.83)$ & 0.70 & 10 & $0.67-2.25$ & $1.36(0.61)$ & 0.37 \\
\hline
\end{tabular}

$\mathrm{N}=$ Number of nests per quadrat of $100 \mathrm{~m}^{2}$.

vegetation and nests, but in the few points where nests were found, vegetation was also found. Therefore, the data suggest that the distribution of $M$. simplex nests is explained by the availability and distribution of resources than to competition, as proposed by Levings \& Traniello (1981) and Cole et al. (2001).

In the quadrats of the plot $\mathrm{C}$ the average nearest neighbor distance varied from $0.91 \mathrm{~m}$ to $2.94 \mathrm{~m}$, while in the quadrats of the plot D it was much higher, varying from $1.07 \mathrm{~m}$ to $9.37 \mathrm{~m}$ (Table II). Keeping a minimum distance between each nest and its nearest neighbor would result in a uniform spacing, contrary to the observations here reported. Physical characteristics as, for example, scattered vegetation, mostly interrupted by marshy and/or flooded areas, and wind direction, may be responsible for the nest distribution pattern of M. simplex in this area. However, biotic factors, such as intra- and interspecific competition, as well as dispersion of winged ants, cannot be discarded.

Acknowledgments. The authors take this opportunity to thank to FAPERGS - Fundação de Amparo à Pesquisa do Estado do Rio Grande do Sul and CNPq - Conselho Nacional de Desenvolvimento Científico e Tecnológico for the scholarships and to Franciele Sacchett and Marta Bencke for the help in field works.

\section{REFERENCES}

Assunção, R. M. 2000. Desenvolvimentos recentes de estatística espacial em ecologia, p. 1-28. In: R. P. Martins; T. M. Lewinsohn \& M. C. Barbeitos (eds.). Ecologia e comportamento de insetos. Série Oecologia Brasiliensis, vol. VIII. Rio de Janeiro, Universidade Federal do Rio de Janeiro, 435 p.

Cole, B. J.; K. Haight \& D. C. Wiernasz. 2001. Distribution of Myrmecocystus mexicanus (Hymenoptera, Formicidae): association with Pogonomyrmex occidentalis (Hymenoptera, Formicidae). Annals of the Entomological Society of America 94: 59-63.

Cordazzo, C. V. \& U. Seeliger. 1995. Guia ilustrado da vegetação costeira no extremo sul do Brasil. Rio Grande, FURG. 275 p.

Della Lucia, T. M. C. 1993. As formigas cortadeiras. Viçosa, TCDL. $262 \mathrm{p}$.

Diehl-Fleig, E. 1995. Formigas: organização social e ecologia comportamental. São Leopoldo, Unisinos. 241 p.

Gianuca, N. M. 1997. A fauna das dunas costeiras do Rio Grande do Sul, p. 121-133. In: R. S. Absalão \& A. M. Esteves (eds.). Ecologia de praias arenosas do litoral brasileiro. Série Oecologia 
Brasiliensis, vol. III. Rio de Janeiro, Universidade Federal do Rio de Janeiro, $270 \mathrm{p}$.

Kempf, W. W. 1972. Catálogo abreviado das formigas da região Neotropical (Hymenoptera, Formicidae). Studia Entomologica 15: 3-345.

Krebs, C. J. 1989. Ecological methodology. New York, Harper \& Row, 654 p.

Levings, S. C. \& J. F. A. Traniello. 1981. Territoriality, nest dispersion, and community structure in ants. Psyche 88: 265-319.

Lopes, B. C. 2001. Ecologia comparativa de Acromyrmex striatus (Roger, 1863) e de Cyphomyrmex morschi Emery, 1887 (Formicidae, Myrmicinae, Attini) em dunas da praia da Joaquina, Florianópolis, SC. Tese de Doutorado, Universidade Estadual Paulista, Rio Claro, 191 p.

Mariconi, F. A. M. 1970. As saúvas. São Paulo, Ceres, 176 p.

Mayhé-Nunes, A. J. 1995a. Filogenia de los Attini (Hymenoptera, Formicidae): un aporte al conocimiento de las hormigas fungívoras. Tese de Doutorado, Universidad Simón Bolívar, Caracas. 274 p.

Mayhé-Nunes, A. J. 1995b. Sinopse do gênero Mycetarotes (Hymenoptera, Formicidae), com a descrição de duas espécies novas.
Boletín de Entomología Venezolana 10: 197-205.

Pillar, V. D. P. 2000. Multivit - multivariate exploratory analysis, randomization testing and bootstrap resampling: User's guide v. 2.0. Porto Alegre, Universidade Federal do Rio Grande do Sul. $131 \mathrm{p}$

Rambo, B. 1954. História natural da flora do litoral Riograndense. Sellowia 6: 113-172

Rambo, B. 1994. A fisionomia do Rio Grande do Sul. São Leopoldo, Unisinos, 473 p.

Ricklefs, R. E. 1993. A economia da natureza. Rio de Janeiro, Guanabara Koogan. 470 p

Waechter, J. L. 1985. Aspectos ecológicos da vegetação de restinga no Rio Grande do Sul. Comunicações do Museu de Ciências da PUCRS, Série Botânica 33: 49-68.

Warburg, I. \& Y. Steinberger. 1997. On the spatial distribution of nests of the ants Messor arenarius and Messor ebeninus. Journal of Arid Environments 36: 671-676.

Weber, N. A. 1982. Fungus ants, p. 250-363. In.: H. Hermann (ed.) Social Insects. vol. IV. New York, Academic Press, 385 p.

Zar, J. H. 1999. Biostatistical analysis. New Jersey, Prentice Hall Upper Sadlle River. 663 p.

Received 27.IV.2004; accepted 05.XI.2004 